\title{
A STUDY OF THE EFFECTIVENESS OF THE ADMINISTRATIVE ANTI-SMOKING MEASURES IN WORK AND PUBLIC PLACES IN THE TOWN OF HASKOVO
}

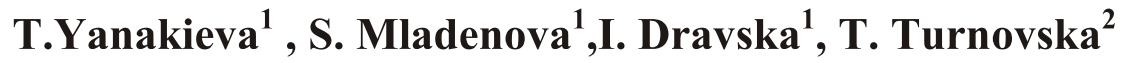 \\ Regional Inspektorate for Public Health Protection and Control-Haskovo ${ }^{1}$, \\ Medical University-Plovdiv ${ }^{2}$
}

Reviewed by: Assoc. Prof. St. Popova, MD, PhD

\section{INTRODUCTION}

Global tobacco consumption is the cause of death for 3 million people per annum (1995), with a tendency to rise to 10 million in the year $2030(1,16)$. Smoking increases the risk of chronic obstructive lung disease ten times, of lung carcinoma in men -22 , and in women - 12 times; respiratory and cardio-vascular diseases are more frequent in smokers, reduction of bone density during the post-menopausal period and disruptions in reproductive functions, including increased risk of infertility, stillbirths, low weight in newborn babies and development of the Sudden Cardiac Arrest Syndrome in nursing infants (15). The negative health effects as a result of passive smoking are also well manifested (14).

Bulgaria is among the countries in Europe with the most serious health problems caused by tobacco smoking; $57 \%$ of smokers in our country are men, $43 \%$ - women, while $53 \%$ of them are 39 or younger. Unacceptably high is the average percentage of smokers amongst doctors $-50 \%$, while $33.3 \%$ of them are heavy smokers (7).

Many of the adverse health effects caused by smoking are reversible and breaking the harmful habit justifies the high cost of all health care procedures and interventions (4). On that account the WHO and the governments of particular countries take various measures to restrict or completely ban smoking in work and public places.

For the present study we set the objective to assess the implementation of the Ministry of Health Decree for Restriction and Ban on Smoking (State Bulletin issue 110/Dec. 17, 2004) in the town of Haskovo, as well as the effect of increased prices of tobacco products in our country.

\section{MATERIAL AND METHODS}

In the year 2005 we surveyed 228 people from the following professional spheres: clothing production $(21.93 \%$ of

\footnotetext{
Address for correspondence:

T. Yanakieva, Regional Inspectorate for Public Health Protection and Control-Haskovo.

E-mail: tanya316@abv.bg
}

all surveyed individuals), civil servants in the state administration $(32.02 \%)$, and workers employed in food-processing $(28.5 \%)$ and in non-food-processing (17.54\%) public establishments. The selected establishments are subject to control by RIPCPH (Regional Inspectorate for Protection and Control of Public Health) - Haskovo for adherence to the Order for the Conditions and System under which an exception can be made allowing smoking in designated areas in enclosed working premises. The survey form which we created specially for our objective contained the following main questions: Do you smoke; if 'yes' - How many years have you been smoking; How many cigarettes a day do you smoke on average; Are you familiar with the consequences for one's health resulting from smoking; If you smoke, what can make you quit smoking; Do you think the issue of designating 'tables for smokers' and 'tables for non-smokers' in catering establishments has been justly settled; In your opinion, is it necessary to set up separate rooms for smokers and non-smokers in public catering establishments; Do you approve of the ban on smoking in public transport, etc.

In the year 2006, after the sharp rise in the prices of tobacco products, we conducted a second survey among the same employees.

\section{RESULTS}

Smokers constitute $45.8 \%$ of all surveyed individuals (a total of 439 individuals), and non-smokers $-54.2 \%$; women are $63.8 \%$, and men $-36.2 \%$. The main findings from the survey are represented in table 1 .

The data about the distribution according to sex and smoking habits (number of cigarettes per 1 day) are presented in fig. 1.

Fig. 2 presents the data about the percentage of those approving of the administrative measures against smoking in the years 2005 and 2006.

\section{ANALYSIS}

The findings showed that $45.2 \%$ of the surveyed smokers wish to quit cigarettes, and $29.5 \%$ of them have made at- 
Table 1. Data from the survey study

\begin{tabular}{|c|c|c|c|c|c|c|}
\hline $\begin{array}{l}\text { Age } \\
(y)\end{array}$ & $\begin{array}{l}\text { Men } \\
(\%)\end{array}$ & $\begin{array}{c}\text { Women } \\
(\%)\end{array}$ & $\begin{array}{c}\text { Administrative } \\
\text { workers }\end{array}$ & $\begin{array}{c}\text { Workers of } \\
\text { clothing } \\
\text { production }\end{array}$ & $\begin{array}{c}\text { Workers in } \\
\text { food-processin } \\
\mathrm{g} \\
\text { establishments }\end{array}$ & $\begin{array}{c}\text { Workers in } \\
\text { communal } \\
\text { establishments }\end{array}$ \\
\hline $15-20$ & 0.68 & 1.82 & 0 & 0 & 1.68 & 11.8 \\
\hline $20-30$ & 7.28 & 15.03 & 20.6 & 22 & 45.4 & 32.9 \\
\hline $30-40$ & 10.93 & 20.73 & 25.7 & 30 & 15.13 & 17.6 \\
\hline $40-50$ & 6.38 & 14.80 & 27.3 & 33 & 31.9 & 25.9 \\
\hline $50-60$ & 6.60 & 11.16 & 21.5 & 10 & 5.9 & 8.24 \\
\hline Over 60 & 2.96 & 0.91 & 4.9 & 5.0 & 0 & 3.53 \\
\hline $\begin{array}{l}<10 \\
\text { Cigarette per day }\end{array}$ & 3.4 & 15.6 & 5.38 & 9.7 & 2.15 & 2.15 \\
\hline 10-20 Cigarette per day & 25.3 & 40 & 27 & 3.23 & 22.6 & 17.2 \\
\hline$>20$ Cigarette per day & 5.7 & 8.8 & 0 & 0 & 7.53 & 3.23 \\
\hline Smoking Duration 10 years & 7.53 & 16.13 & 7.53 & 4.3 & 13.98 & 5.38 \\
\hline Smoking Duration 15 years & 8.60 & 10.75 & 6.45 & 3.23 & 7.53 & 5.38 \\
\hline Smoking Duration 20 years & 3.23 & 10.75 & 5.4 & 0 & 4.3 & 3.23 \\
\hline
\end{tabular}

tempts to do so. Health problems are pointed out as a leading motive for quitting cigarettes (for $60.37 \%$ of smokers); $93.55 \%$ of all the surveyed individuals are aware of the principal health consequences as a result of tobacco smoking. According to the data from the survey study, $29.49 \%$ of smokers would give up cigarettes because of the rise in prices. The stricter administrative measures are the reason for giving up cigarette smoking for only $5.53 \%$ of smokers. In practice however, the smokers surveyed in the year 2005 were $42.5 \%$, and in the year $2006-47.5 \%$. This indicates that neither health awareness, nor the increased prices of cigarettes, nor the administrative measures (the Ministry of Health Decree) have reduced their number.

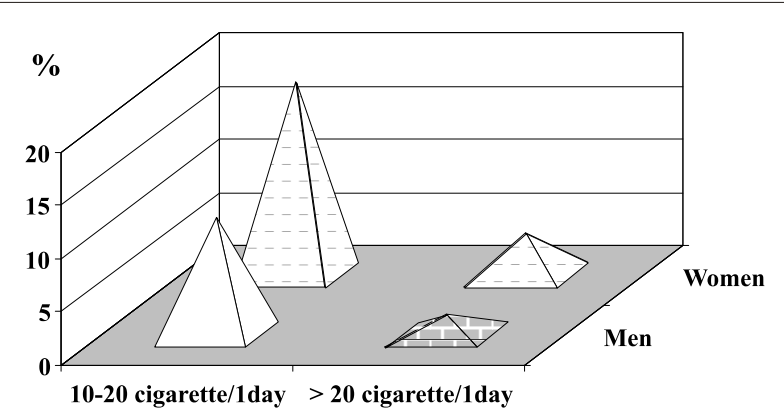

Fig. 1. Distribution according to sex and smoking habits (number of cigarettes per 1 day)

The percentage of smokers with the longest duration of 'regular habit' (more than 20 years) is the highest in both surveys, both in men and in women. It is observable that besides the longer 'regular habit' duration the women participating in this survey smoke a larger number of cigarettes daily compared with men (fig. 1).

Almost 1/3 of the surveyed medical workers are smokers which means that they would have difficulty in successfully carrying out convincing health-educational activity among the people they provide service for.

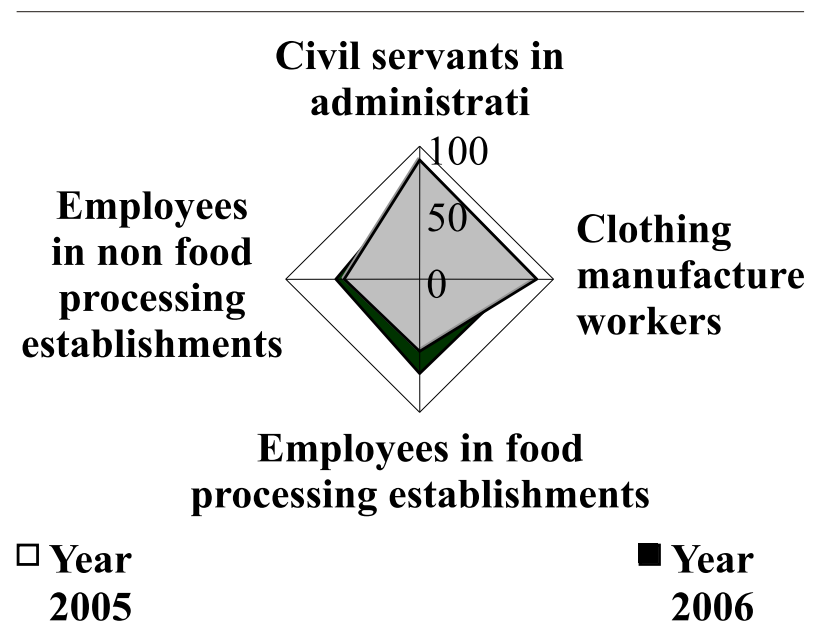

Fig. 2. Percentage (\% of the individuals surveyed in the respective group) of those approving of the measures for restriction and ban on smoking

The proportion of approval for the measures for restriction of smoking in public places and in enclosed working pre- 
mises has grown compared with the year 2005, particularly amongst the surveyed individuals in clothing production and amongst administrative workers, but it has decreased with $17 \%$ (from 70.7 to 53.7 ) in individuals employed in catering establishments. This probably has to do with the fact that numerous small restaurants and coffee shops cannot provide separate rooms for smokers and non-smokers as it is required in the above-mentioned decree and they are afraid of losing their clients. On the other hand, the large number of these establishments predetermines their significant effect in society - they provide income for many families. This fact compelled the Ministry of Health to liberalize the decree, allowing for 'tables for smokers' and 'tables for non-smokers' in the same room. This compromise, however, according to the majority of those surveyed, undermines the real purpose of the undertaken administrative measures for restricting smoking. That is why the percentage of those approving of separate rooms for smokers and non-smokers in the public catering establishments has grown (from $62.5 \%$ in the year 2005 to $76.04 \%$ in the year 2006). It has to be mentioned that about $25 \%$ of smokers in our country consider smoking to be prestigious. Critical to the measures of the government against smoking in public places, they most aggressively oppose all restrictions because they impose a change in their lifestyle (10).

The surveyed individuals' approval of the ban on smoking in public transport has grown from $76.6 \%$ in the year 2005 to $78.34 \%$ in the year 2006 .

\section{CONCLUSION}

1. Health problems (in $60.37 \%$ ) and the higher prices of cigarettes (in $29.49 \%$ ) have been pointed out as a leading cause for smokers to give up the harmful habit.

2. The number of those approving of the measures restricting smoking in public places and in enclosed work premises has grown.

3. According to $76.04 \%$ of all of the individuals surveyed it is mandatory to designate separate rooms for smokers and non-smokers in public catering establishments.

\section{LITERATURE:}

1. Crofton J., D. Simpson. Tobacco: A Global Threat, 2003, Sofia, 1-30.

2. Dockery DW et al. Am Rev Respir Dis. 1985 Apr; 131(4): 511-20. Distribution of forced expiratory volume in one forced vital capacity in healthy, white, adult never-smokers in six U.S. cities $3^{\text {rd }}$, Speizer FE.
3. Dejmek J. The Exposure of Nonsmoking and Smoking mothers to Environmental Tobacco Smoke during Different Gestational Phases and Fetal Growt. Environmental Health Perspectives volume 110, 2002, 6.

4. Fagerstцm K. Health Consequences and Benefits of Cessation. The Epidemiology of Smoking. Drugs; 2002 Supplement 2, Vol. 62 Issue 11, pl, 9 p.

5. Frank-Piskorska A. et al. Evaluation of pulmonary function tests in a population of young men from different regions of Poland. Pol Merkuriuz Lek., 1997, 3(16), 174-176.

6. Goren AI, Hellman S. Respiratory conditions among schoolchildren and their relationship to environmental tobacco smoke and other combustion products. Arch Environ Health 1995, 50 (2), 112-118.

7. Health Ministry of Bulgaria, National centre of Public health. National representative study about smoking among doctors. Forum Medicus Newspaper, issue 11/ March 13, 2006.

8. Hugging M. Risk Factors associated with chronic obstructive lung disease. Ann NY Acad Sc.1991, 624, 7-17.

9. Luttmann H. et al. Normal values for spirometry lung function values and peak flow for 7-18 -year-old probands. Pneumologie .1997 Jan;51(1):47-54

10. National Representative Study, conducted by NCIPO in the year 2005 .

11. Ortega S. J. Repercussion of risk factors associated with the development of chronic bronchial pathology on pulmonary function in children. An Esp Pediatr. 1990, 32(5), 399-406.

12. Pope CA $3^{\text {rd }}$, Kanner RE. Acute effect of PM 10 pollution on pulmonary function of smokers with mild to moderate chronic obstructive pulmonary diseases. Am Rev Respir Dis., 1993, 147 (6), 1334-1335.

13. Rizzi M. et al. Environmental tobacco smoke may induce early lung damage in healthy male adolescent. Chest, 2004, 125 (4), 1387-1393.

14. Sockrider M. The respiratory effects of passive tobacco smoking. Curr Opin Pulm Med., 1996, 2 (2), 129-133.

15. Tobacco information and Prevention Sourse (TIPS ); The Health Consequences of smoking : A report of the surgeon general: "Health effectof cigarette smoking", 2004, available at : http://www.cdc.gov/tobacco/factssheets/.

16. WHO. Tobacco free initiative: Building blocks for tobacco control: a handbook, (Tools for advancing tobacco control in the 21 st century ), 2004, p.6 available at : http:// www.who.int/tobacco/resourses/pub;ications/tobacco control_handbook/en.

17. WHO/Tobacco free initiative /Regional Office for Europe: "Why is tobacco a public health priority ?" available at : http: // www.who.int/topics/tobacco /en. 